\title{
Ceremonias de ostentación y prominencia en la subcultura delictual chilena
}

[Ceremonies of ostentation and prominence in Chilean criminal subculture]

\author{
Alejandro Romero-Miranda (i) \\ Universidad La República, Chile
}

\begin{abstract}
Resumen
El propósito de esta investigación fue analizar la ostentación que sujetos varones con identificación delictual hace para presumir de sus habilidades delictivas y adscribir al imaginario fundante y contemporáneo del choro ladrón en redes sociales. La investigación se realizó entre enero y mayo del 2020 y en ella se analizaron 16 videos grabados por los propios sujetos disponibles en redes sociales. Los resultados muestran que serían tres los principales capitales que se despliegan en las ceremonias de ostentación: el capital delictual, el capital de valor, y el capital de daño. En conjunto, los tres capitales entregan un cuadro comprensivo del rol y la trascendencia de la ostentación en la consecución de la prominencia en la subcultura delictual chilena.
\end{abstract}

Palabras clave: delincuencia, ostentación, choro ladrón, subcultura, redes sociales.

\begin{abstract}
The purpose of this research was to analyze male subjects who identify as felons and the ostentation they exhibit in order to show off their criminal skills and affiliate themselves with the fundamental and contemporary imaginary of the thieving choro on social media. The research took place between January and May 2020 and involved the analysis of 16 videos recorded by the subjects themselves and made available on social media. The results reveal three main forms of capital displayed in ostentation ceremonies: criminal capital, value capital, and harm capital. Together, the three capitals provide a comprehensive picture of the role and significance of ostentation in achieving prominence within the Chilean criminal subculture.
\end{abstract}

Keywords: crime, ostentation, choro thief, subculture, social networks. 


\section{INTRODUCCIÓN}

En las sociedades contemporáneas, el uso de internet y de las redes sociales se han instaurado como un espacio donde los sujetos se relacionan e interactúan (Caro, 2012; Igarza, 2010) intercambiando y haciendo circular información, imágenes, textos, u otros. Internet es un espacio de despojo y ostentación (Reygadas, 2018) que, en muchos casos, atenta contra el uso racional y precavido que se espera del ciber espacio (Hütt, 2012). Aplicando la óptica de Augé (1992) con las redes sociales, internet dejo de ser un no lugar. La red de internet se ha transformado en el nuevo escenario de la modernidad y en una herramienta destinada a suplir o alterar signos y símbolos que en la realidad cotidiana se disponen de forma indeseada o desfavorable (Britto \& Ordoñez, 2012; Featherstone, 1991; Reygadas, 2018). Las redes sociales se posicionan como un dispositivo que anestesia la autocrítica y las posibilidades de fracaso, permitiendo obviar las dificultades y tensiones de la vida real por medio de la fetichización de signos y símbolos que pasarán a conformar el entramado psíquico (Baudrillard, 2000; Moulian, 1998) patentando un consumo de imágenes que generan un goce esclavizante (Lasch, 1979; Pardo, 2015). Las redes sociales engendran la promesa de una autorealización por medio de un hedonismo autoilusorio (Britto \& Ordonez, 2012; Carosio, 2010; Del Prete \& Redon, 2020; Featherstone, 1991; Hütt, 2012; Pardo, 2015), que apela a conseguir lo mejor que haiga (sic) en un escenario donde el registro mítico y fantasioso de la autopercepción termina imponiéndose sobre la razón (Baudrillard, 2000).
Esta dinámica instalada como valor en las redes sociales, no es ajena a la subcultura delictual chilena que usa esta red para mostrar su poder en las relaciones sociales cotidianas, la condición social que detentan, sus patrones y estilos de consumo, su estética reguetonera, la narcomáquina (Reguillo, 2010; Rincón, 2009), ostentar sobre su trayectoria delictiva y la profusión en el delito (Romero, 2017). Estos dos últimos fenómenos son de gran interés para la sociología delictual por su recurrencia, complejidad y riqueza discursiva. De esta manera, las redes sociales se trasforman en un nuevo espacio social o campo (Bourdieu, 1997, 2000) donde los sujetos diseminan su capital económico, cultural, y social a través de imágenes, signos, y significantes. Esto para imponer su subjetividad en los individuos que operan en dicho espacio social.

La subcultura delictiva involucra creencias, valores, discursos, y prácticas de un grupo de sujetos que genera conductas contra normativas o desviación (Cohen, 1955; Cohen, 1972; Cooper, 1989, 1994, 2007; Guemureman, 2006; Isla, 2011; Romero, 2017; Sánchez, 2016) que se contraponen a la cultura hegemónica. Este capital opera en forma de ceremonias de ostentación delictual, que se definen como prácticas de alardeo y exhibición pública de acciones y bienes que buscan denotar una trayectoria delictiva prominente con independencia del correlato real. Estas ceremonias obedecen al esfuerzo de los sujetos por mostrar una trayectoria delictiva exitosa acorde a las representaciones sociales de la actividad delictiva y su figura fundante: el choro-ladrón. 

ostentación y prominencia en la subcultura delictual chilena. Revista de Sociología, 36(2), 21-33. https://doi.org/10.5354/0719-529X.2021.65568

El choro-ladrón personifica la astucia, el arrojo, el manejo de técnicas delictivas y la adherencia a los códigos del hampa que lo hacen un referente profesional para el resto de los miembros de la subcultura delictual (Cooper, 1994; Sutherland, 1991). El choro-ladrón es un arquetipo propio del siglo XIX (León, 2008; Lozoya, 2014; Palma, 2011; Salazar $\&$ Pinto, 1999), que en el devenir y estructuración de las sociedades modernas se enaltece como imaginario colectivo delictual (Cooper, 1989, 1994). El choro-ladrón es una figura que surge al alero del bandidaje rural chileno durante el siglo XIX. La figura del bandido personifica al sujeto que hace del robo su oficio y sustento de vida. Esto le lleva a generar un código de conducta destinado a diferenciarse del delincuente ocasional u oportunista (Lozoya, 2014). Este código ético del choro-ladrón es un código consuetudinario creado para preservar la actividad, asegurar el grupo, y crear identidad (Palma, 2011), estableciendo así, diferencias entre choro-bandido (landrón profesonal) y delincuente ocasional no profesional. El choro-ladrón deprecia la violencia y las amenazas para impresionar y hacerse notar, repudia a quienes se valen del mero daño para perpetrar ilícitos, no daña a su comunidad, se vale por sí mismo ante las adversidades, no delata a los otros miembros de la cultura del hampa, no trabajar para nadie y posee una trayectoria delictiva desde la infancia (Cooper, 1994). El choro-ladrón planifica el robo aplicando su inteligencia $\mathrm{y}$ astucia en su ideación y ejecución (León, 2008), y usa su la capacidad de acumulación de capital para la subsistencia familiar y solventar el retiro delictual (Salazar \& Pinto, 1999). Aun cuando esta imagen se transforma en el deber-ser de quienes se identifican con la subcultura del delito en las sociedades contemporáneas, la ostentación de capital delictivo a partir de los años ochenta (Palma, 2011), pone en relieve nuevos elementos que adicionan y actualizan esta figura fundante.

La ostentación mediática busca denotar la socialización, el rol y el estatus del sujeto en la subcultura delictiva y fortalece su adosamiento a la cultura hegemónica por medio de un modernismo actitudinal que mezcla la consecución de metas y éxito por medios alternativos que generan conflictos criminógenos (Cooper, 1989). Los desviados, enemigos de la sociedad, vástagos del mal (Romero, 2017) o demonios populares (Cohen, 1972), antes apesadumbrados por la marginación y el etiquetaje (Tsukame, 2016b), hoy hacen de esos descalificativos un valor subcultural que levantan en las redes sociales con pomposa estridencia, viralizando así el miedo que revitaliza la violencia (Isla, 2011) y limita el alcance explicativo de la teoría subcultural de los años 60 (Guemureman, 2006), permitiendo abrir la génesis delictiva a la causalidad de los opuestos (Ruggiero, 2005) donde la conducta delictiva no se comprende solo por la carencia relativa sino por su contrario: la abundancia relativa o el exceso de algo. Con esto, se expande la cuna etiológica del ser delictivo. En adelante, cualquier lugar de la estructura social es un fértil valle para la proliferación de conocidos $u$ exóticos demonios populares. Así, lo antisocial se funde camaleónicamente con lo prosocial (Tsukame, 2016a), sobre todo, cuando quienes cometen los delitos son los de siempre y también los jóvenes ricos y poderosos (Guemureman, 2006).

Tomando en consideración lo antes expuesto, este trabajo busca indagar y comprender el sentido de las prácticas de ostentación y exhibición de armamento, botines y elementos de valor, que sujetos infractores 
de ley realizan en las redes sociales. Para lo cual, se buscó analizar la conducta de ostentación que sujetos delictuales varones muestran y exhiben en internet y redes sociales, analizar elementos actitudinales, discursivos, kinésicos y paralingüísticos extraídos de los videos que circunscriben las prácticas de ostentación e identificar las representaciones sociales e imaginarios colectivos que sustentan la ostentación y estructuran las interacciones entre pares.

\section{MÉTODO}

Para llevar a cabo esta investigación buscaron videos caseros y reportajes encontrados en internet (Google y YouTube) relacionados con la conducta de ostentación que infractores de ley describen. Las palabras claves de búsqueda de los videos fueron: ostentación delictual; prácticas de ostentación delictual; delincuencia y ostentación de armamento; robo y ostentación; robo y exhibición de armamento; delincuencia y exhibición de elementos robados; ostentación de ficha y daño; ostentación desde la cárcel. Esta consideración es relevante, pues, los videos seleccionados no hacen referencia directa al acometimiento de actos delictivos, sino que centran su dinámica en la exhibición de elementos adquiridos mediante la práctica delictiva a nivel genérico o delitos perpetrados contra el patrimonio, propiedad privada o personas. Por ello, las palabras clave de búsqueda no consideraron términos únicos como: robos, atracos, asaltos ni categorías similares. Los criterios para la búsqueda y selección de los videos fueron que (a) se tratara de grabaciones de carácter individual o grupal con una antigüedad de creación menor a cinco años al mes de enero 2020; (b) que hubiesen sido hechas por los propios sujetos con sus dispositivos móviles; (c) la finalidad o motivo central del video debía ser la ostentación de sí mismo, de armamento o botines producto de delitos contra el patrimonio, la propiedad privada o las personas; (d) los videos podían ser grabados en el medio libre o en la cárcel; y (e) los participantes (actores principales de los videos) debían ser hombres jóvenes o adultos. Esta búsqueda permitió seleccionar 16 videos, de los cuales, 13 corresponden a grabaciones directas de los sujetos con sus dispositivos telefónicos, y 3 a reportaje donde la ostentación es el foco de discusión en base a videos grabados por los propios delincuentes. Los videos fueron revisados y descargados durante el mes de enero del 2020. Los 16 videos constituyen 86 minutos de grabación que fueron codificados con una pauta de observación que fue validada y ajustada mediante su aplicación a un video referencial. Esta pauta centró la observación en torno a dos ejes: (a) semiótica (kinésica), paralingüística, y discurso proferido por los sujetos y (b) representaciones, significados, e imaginarios que validan y estructuran la ostentación desde el discurso. Las observaciones y anotaciones fueron analizadas en torno a los ejes teóricos antes mencionados y se realizó un análisis hermenéutico (interpretativo-comprensivo) para el que se crearon categorías de ostentación, de capitales delictivos, la kinésica y paralingüística de las imágenes, y se tradujeron al castellano los conceptos en coa (i.e., lenguaje de la contracultura del hampa) usados en los videos para su comprensión por parte del lector. 


\section{RESULTADOS}

En los videos se aprecia se pueden identificar tres componentes recurrentes y transversales que de las ceremonias de ostentación: la ostentación del capital delictual, la ostentación del capital de valor y la ostentación del capital de daño. Estos tres componentes pueden ser concebidos como acciones de autopromoción y como estrategias de superposición mediática destinadas a reafirmar o alcanzar la posición deseada en el entramado de relaciones que se generan al interior de la subcultura delictiva. De aquí, que muchas de estas ceremonias puedan ser planteadas bajo el esquema de la interacción dramatúrgica (Goffman, 1982, 1989) destinada justamente al manejo de las impresiones.

\section{Ostentación del capital delictual}

El alardeo de la experiencia y de la trayectoria delictiva - entendida como hechos comprobables que conforman el prontuario delictual- es el elemento basal de toda ceremonia de ostentación y el principal precursor de los restantes componentes. Esta, junto al capital delictivo -entendido como experiencias y conocimientos que conforman el acervo delictualson los vectores primigenios que los sujetos despliegan para lograr el reconocimiento y posicionarse en un lugar de prominencia en el entramado de relaciones que allí se disputan. El cruce de estos dos elementos da como resultado una ficha o currículo delictual que entrega datos referenciales del sujeto para su reconocimiento y posicionamiento en la dinámica de pares (Romero, 2017, 2019). La ficha delictual es el propio capital simbólico que es usado para lograr legitimación y para posicionarse como el vi’o (coa para designar al sujeto "vivo", "choro", con trayectoria delictiva prestigiosa) en oposición al perkin (coa para designar a una persona denigrada, sin autonomía, mandada por otros, sin trayectoria delictual prominente). Así, el currículo delictivo muestra cómo el sujeto está desplegando su capital delictivo, pero también del cómo ha forjado su trayectoria delictiva. Por ende, la ostentación del capital delictivo no es sólo la presunción de habilidades que denotan éxito delictual, sino la exposición mediática de su identidad como se muestra en los siguientes diálogos extraídos de algunos videos:

¡Mírame hijo 'e la bastarda! aquí ando to'o ready con el X mi hermano. Aquí to’o galáctico... Aquí, ro'ando güeno, puro primer corte. Yo no ando ro'ando negocio' como vo' chuche-tu-ma're, no me hago la ficha con los longi'. Yo soy de pana... pura bencinera, puro portonazo fino. No como vo' perkin. [¡Mírame idiota! aquí ando listo con el $\mathrm{X}, \mathrm{mi}$ hermano. Aquí preparado... robando, sólo cosas de alto valor. No robo negocios pequeños como tú estúpido, no busco fama entre los tontos. Yo soy de los ladrones de verdad... robo solo en estaciones de servicio y automóviles de alta gama en las casas. No como tú que eres un mandado.]

F, esto es pa' vo', hijo 'e la gran maraca, que te hací' la ficha con pura falacia. ¿Cuándo te hai' paquea'o? iperkin culia'o, malaya culia'! ¿Cuándo te hai' pega'o un connota'o? Andai' de traficante vendiéndole gue'á' a los cauros chico' chuchetumare. [F, esto es para ti estúpido que te haces fama inventándote robos. ¿Cuándo te has enfrentado 

ostentación y prominencia en la subcultura delictual chilena. Revista de Sociología, 36(2), 21-33. https://doi.org/10.5354/0719-529X.2021.65568

con la policía? Estúpido incompetente. ¿Cuándo has robado algo importante? Andas vendiendo drogas a los niños estúpido]

De esta manera, la ostentación del capital delictual busca mostrar premeditadamente la personificación del choro ladrón en sus técnicas y su código de conducta. En este sentido, los diálogos de los videos analizados muestran un discurso que gira en torno a la importancia del inicio precoz de la conducta delictiva, de los enfrentamientos con la policía como proceso de aprendizaje del oficio (escapar de su asedio o contar con reclusiones a cuestas). El discurso de los sujetos muestra desprecio por el trabajo formal y asalariado que ven como un acto de sumisión que se contrapone al ideal del choro-ladrón que trabaja para sí mismo: "te jurai' vi'o y te funaron en la contru" [te crees choro, pero vieron trabajando en una construcción] reclamaba un sujeto en uno de los videos demostrando así la connotación denigrante del trabajo asalariado. Otro de los aspectos destacados en torno a los cuales giran los videos es la importancia del genograma delictual. La exhibición del linaje antisocial del sujeto, en razón de la cantidad y prestigio de familiares con prontuario e identificación delictual: "yo tengo prole en cana po chuchetumare" [tengo familiares en la cárcel estúpido], "mi hermano está haciendo 20 años, mi tío esta perpetuo ¿y vo’? ¿a quién tení a'entro?” [mi hermano está cumpliendo condena por 20 años, mi tío tiene cadena perpetua ¿y tú? ¿tienes familiares en la cárcel?]. Tan relevante como la propia trayectoria delictiva es la calidad delictual y prominencia de quienes forman parte de las relaciones cercanas del sujeto o participan con él en actos delictivos. Quienes cometen delitos juntos se organizan en torno a vectores de afinidad, identificación, y experiencia delictual que brindan mayores garantías de éxito a la consumación del delito y dan confianza de no ser delatado si el acto es fallido. De los videos se desprende, que los sujetos con identificación delictual están constantemente probando su calidad y masculinidad entre pares, donde la categoría perkin es un etiquetado que deja al sujeto en una situación de susceptiblilidad de abusos, vejaciones y burlas, pasando este hecho a formar parte constitutiva del reconocimiento entre pares y posicionamiento endogrupal. Ello explica la recurrencia en los videos de afirmaciones como: "Yo nunca he si'o perkin po hijo la perra" [Yo nunca me he sometido a otros]. Se desprende de las imágenes analizadas que el grado de relevancia y prestigio del delito cometido no está dado solo por la consumación exitosa del hecho planificado, sino por la cantidad y valor de las especies extraídas, por hacer "choreos güenos" (robo de cosas caras) o ser “de puro' connota'os" (especializarse en robos de alta connotación). Estos hechos y los videos que hacen y suben a redes sociales permiten a los sujetos probar su calidad delictiva de manera constante para obtener y mantener el reconocimiento de los pares. Todas estas aseveraciones, pueden ser sintetizadas en ocho vectores de reconocimiento: el inicio temprano de la actividad delictiva, hacer del robo un oficio y sustento de vida, acreditar experiencias en burlar el asedio policial o ser conocido por la policía (i.e., haberse paquea'o), no haber sido denigrado a la categoría de perkin, contar con prontuario, tener un genograma delictual, estar inserto y ser conocido por pares en el circuito de relaciones delictivas (lazograma) $\mathrm{y}$, haber superado las pruebas de ficha entre iguales. Estos elementos dan origen al imaginario actualizado 

ostentación y prominencia en la subcultura delictual chilena. Revista de Sociología, 36(2), 21-33. https://doi.org/10.5354/0719-529X.2021.65568

y complementario del choro: el flaite-ladrón. Un personaje de clase social baja y comportamiento amenazante y extravagante (Rojas, 2015; Tsukame, 2016b) que entremezclando la estética del reggaetón, la suntuosidad narco y el narcisismo capitalista iconizará la masculinidad delictiva (Romero, 2018) del hampa chileno del siglo XXI. Así, los sujetos forjan su autopercepción y su representación delictiva diferenciando el choro-ladrón del picao-a-choro. El picao-a-choro, es el delincuente que no encaja en los patrones propios del choro-ladrón (Isla, 2011), pues su autopercepción positiva y prominente no se condice con la percepción negativa y desacreditada que sus pares tienen de él. El picao-a-choro adopta ciertos elementos del modelo fundacional, pero contradice aquellos que se consideran esenciales.

A ese gue'on lo funamos de la galería ocho hace cualquier año... Cuando llego a la Peni' lavó. Despué' se fue a los hermanos. Ahí estuvo entero sometio, no podía salir de la pieza, ¡Pa’ qué po’! despué se jue pa' la calle cuatro y de ahí pa' Colina. Ahora anda haciendo video a lo maldito, y jese gueon nunca ha si'o asesino! el gueon nunca ha teni'o una cuchilla llena de grasa hasta el tope en la mano. [A este lo dejamos en evidencia en la galería ocho hace tiempo. Cuando llegó a la Penintenciaría de Santiago fue obligado a lavar ropa de otros reclusos. Después se fue con el gripo de reclusos evangélicos. Ahí estaba completamente sometido, no podía salir de la pieza ipara qué exponerse a más humillación! Después se fue a la calle cuatro (otro sector de la cárcel) y de ahí a la cárcel de Colina. Ahora hace videos pretendiendo ser choro, pero inunca ha sido asesino! Ese estúpido nunca ha tendido un cuchillo lleno de grasa hasta el tope en la mano].
Así, mientras el choro-ladrón personifica el peligro, el picao-a-choro debe inventarlo y representarlo porque no le es propio. Mientras el choro oculta su oficio a fin de pasar desapercibido, el picao-a-choro lo exhibe, se muestra y ostenta porque es la única forma de obtener reconocimiento. Mientras el primero actúa y se defiende solo, el segundo necesita de otros para salir del paso. Mientras el choro utiliza el ingenio y la astucia para perpetrar sus ilícitos, es decidido, y lo identifica su trayectoria prestigiosa, el picao-a-choro hace de la violencia y la intimidación su móvil de acción, es pura amenaza y sólo se jacta de actos aislados que muestra como hazañas. Si el chorizo delinque como sustento del hogar y la familia, el picao roba en lo principal por beneficio personal; mientras el choro se identifica con el entramado social e historicidad del barrio (un vecino más), el picao aspira a controlar la población y ser su dueño engendrando respeto a través del temor. De esta manera, la ostentación del capital delictivo supone ante todo, evidenciar la adscripción del choro-ladrón desde su adecuación moderna y funcional (el flaite-ladrón), figura que no sólo permitirá traspasar la imagen fundacional a las nuevas generaciones que saltan al ruedo, sino además, hacerla comprensible, identificable y asimilable, en razón de una representación social concreta, cotidiana y experiencial que en la actualidad aglutinará la subcultura delictiva.

\section{Ostentación del capital de valor}

Este componente de la ostentación se relaciona con mostrar a través de imágenes o palabras el fruto de la praxis delictual, es decir, los elementos robados o adquiridos con el dinero obtenido a partir 

ostentación y prominencia en la subcultura delictual chilena. Revista de Sociología, 36(2), 21-33. https://doi.org/10.5354/0719-529X.2021.65568

de los delitos cometidos a fin de dejar en evidencia lo exitoso de su trabajo y alardear ante los pares. Un ejemplo de esto se aprecia en uno de los videos analizados en el cual un sujeto desde la cárcel se jacta de sus logros ante la cámara. Les reprocha a dos sujetos "son pura boca basuras culia" [son unos fanfarrones mentirosos] y luego la cámara enfoca el suelo, donde se encuentran aproximadamente 14 pares de zapatillas de marcas reconocidas y alto valor, el protagonista increpa: “¿las conocí?? [ilas conoces], y luego muestra dos cinturones diciendo "¿conocí esta marca? ¿las Gucci, las Louis Vuitton?" y se vuelve sobre las zapatillas preguntando nuevamente "¿las conocí? las Merrel, los Caterpillar", para finalmente mostrar dos relojes (uno en cada mano) comentando de forma despectiva "pe[d]azo [d] e reloj po' hijo, te tapizo hijo, te tapizo" expresión que quiere decir que con el valor de esos dos relojes te podría vestir de pies a cabeza.

La ostentación de valor entonces, se relaciona con la exhibición de elementos de alto valor comercial y simbólico en la subcultura delictual como por ejemplo joyas, relojes, zapatillas, entre otros (Britto \& Ordoñez, 2012; Zúñiga, 1991). El valor simbólico de estos elementos se entroniza con la propia conceptualización del flaite-ladrón, conjunción de la estética reggaetonera (Luci \& Soares, 2019), la suntuosidad narco (Reguillo, 2010; Rincón, 2009) y el consumo narcisista (Baudrillard, 2000; Carosio, 2010; Featherstone, 1991; Moulian, 1998; Pardo, 2015; Ponce-Cordero, 2016) que al mezclarse dan como resultado una adaptación criolla sui géneris del ladrón prominente, mezcla de artista, divo y gánster. Con el flaite-ladrón, la ostentación del capital delictual y de valor se naturalizan como práctica social del delincuente prominente.
Así, la ostentación del flaite-ladrón es una demostración de moda, de estilo, de estética, pero sobre todo, de capacidad de consumo que se transforma en el símbolo de la prominencia y de las habilidades delictivas que permite la superposición sobre los pares, que identifica la búsqueda de beneficio económico y la gloria. Esta concepción del consumo posee dos elementos que dan profusión a la ostentación: el concepto mismo del valor atribuido a los objetos por los individuos que escapa de la lógica de consumir para tener que es reemplazada por una lógica de consumo para experiencia, esto es, disfrutar del objeto en su transitoriedad, en su posesión pasajera, en su finitud, dada la imposibilidad de adquirirlo en propiedad. De ahí que, como se aprecia en los videos, un sujeto no puede ostentar la compra de un auto de alta gama, pero sí puede presumir de haberlo robado y conducido. Lo mismo ocurre con las joyas de alto valor, aunque prontamente se verá en la obligación de venderlas. Ambos ejemplos muestran el sentido del consumo de la praxis delictiva contemporánea, donde la ostentación no deviene del tener (propiedad), sino, del usufructo temporal del objeto bajo la percepción de su finitud (posesión), finitud que engendra a su vez, el propio desapego al objeto. Esto último nos lleva a un segundo elemento que circunscribe las ansias de ostentación en los videos: el despilfarro. Que podemos entender como un acto que lleva al individuo a desprenderse sin remordimientos de objetos (e.g., obsequiándolos) con la finalidad de presumir del valor de esos objetos y de sus habilidades delictivas para obtenerlos cuando se desee (Romero, 2017). Para el flaite-ladrón, la ostentación se transforma en una relación social cuando el acto de presumir tiene asidero en la 
realidad cotidiana y no es mera fantasía. De aquí entonces, que la ostentación será criticada y repudiada cuando se genere sólo en la virtualidad y carezca de sustento real, cuando tenga por finalidad, la intención de imponer una imagen alterada e idealizada del sujeto (lógica del pica-a-choro).

\section{Ostentación del capital de daño}

$\mathrm{El}$ alardeo es un elemento inmanente en la figura del choro contemporáneo o flaite-ladrón. Sin embargo, no toda ostentación es considerada como un insumo de prominencia. Tal es el caso de la ostentación del capital de daño, que podemos definir como la cuota de peligrosidad, maldad y violencia, que el sujeto es capaz de mostrar y utilizar de forma sistemática y desproporcionada en su praxis delictiva. Como han mostrado otros (Cooper, 1994; Isla, 2011; Romero, 2017, 2019; Tsukame, 2016a) el desprestigio de la ostentación del capital-daño en la subcultura delictiva contemporánea proviene de la idea que concibe al daño como una estrategia para suplir la falta de habilidades y competencias mentales para hacer del robo, como muestra el siguiente extracto de un video:

Aquí somo' pura mente, arrastrando cajero, choriando banco ¿y vo’? al puro lanzazo, puro cogoteando malaya culiá'.

[Aquí aplicamos el ingenio para robar cajeros automáticos y asaltar bancos. En cambio, tú sólo haces robos por sorpresa, solo asalto con violencia bueno para nada].
El robo inteligente, planificado, que pone en evidencia la viveza y la astucia del ejecutor. La mera fuerza queda para el delincuente común que carece de experiencia, oficio y técnica. Para el flaite-ladrón, el daño y la violencia no se presuponen como elementos de acción, sino que son el resultado del azar o contingencias que complican la ejecución del plan trazado, incluso cuando la praxis delictiva se adorne de amenazas como elementos recurrentes (Cooper, 1994; Domenech \& Iñiguez, 2002; Muñoz, 1990). Por ello, la ostentación de daño en redes sociales es atribuida como inherente a quienes no poseen trayectoria ni capital delictivo prominente; entonces, la ostentación del daño es una conducta propia de los "mostrados", de los "engrupíos", del "flaite-de-cartón", en pocas palabras; del picao-achoro. Esto lleva a pensar que la ostentación de daño se erige desde el tánatos, desde la lógica de la muerte. Esto no sólo por hacer del miedo el lenguaje que circunscribe la prominencia sino por pretender aniquilar la trascendencia de la trayectoria delictual como vector primigenio situando a la violencia en su lugar. De este modo, el espíritu destructivo que subyace en la ostentación del daño, no sólo busca eclipsar a los restantes componentes, sino que además, aboga por transformarse en el principal y superlativo vector de prominencia, donde el temor y la violencia latente, suplan la escasez de capital delictivo brindando nuevas oportunidades de reconocimiento y aceptación que redibujen la jerarquía. 


\section{CONCLUSIONES}

En el relato de la delincuencia moderna, la ostentación juega un rol importante como mecanismo de fortalecimiento y refuerzo de la trayectoria y capital delictivo. En este sentido, las redes sociales son un escaparate para presumir de las habilidades que tienen su correlato y fundamento en la realidad cotidiana, actuando como un nuevo campo donde se disemina y extiende el capital simbólico (Bourdieu, 1997, 2000). Con esto, el choro sale del anonimato y se presenta como un arquetipo más de la sociedad del consumo mediatizado. El ciber espacio también se ha transformado en una oportunidad para que el picao-a-choro pueda acceder al reconocimiento y la prominencia que no consigue de forma presencial al interior de la subcultura delictiva, para lo cual, recurre al manejo de impresiones y a ostentar el capital de daño como motores de reconocimiento. De este modo refunda su historia y habilidades, alineando su imagen con la figura fundante del inconsciente delictivo, luciendo como la personificación aparente o vedette (Bebord, 1967) de la prominencia y el prestigio.

Las redes sociales son un receptáculo para la lucha del capital global (Bourdieu, 1997, 2000) entre el choro-flaite y el picao-a-choro. Esta disputa que tendrá como centro, el mantenimiento del currículo delictivo y el posicionamiento en la jerarquía subcultural, en contraposición a la lógica mediática, que busca suplantar la ficha delictiva por la violencia como centro del deber-ser y del respeto entre pares, transformando el paradigma delictivo de eros en el paradigma de tánatos). Este cambio paradigmático, tiene su correlato en el debilitamiento en la ideología delictiva del siglo XIX que, con adecuaciones y actualizaciones, el flaite-ladrón ha intentado mantener bajo la lógica colectiva, reforzando creencias e ideales supraindividuales. Estos mismos preceptos que el picao-a-choro usa subjetivamente y personaliza, generando discursos propios que han visto en la relativización de la época la oportunidad para resignificar la prominencia y reconocimiento delictual. El picao-a-choro se presenta como la personificación del delito en la modernidad líquida (Bauman, 2008), como el habitante de las diásporas, negado por sus pares y preso del miedo a la incertidumbre (Bude, 2017) que busca cristalizar un modelo que actué como referente identitario, donde lo performativo reemplace al contenido y la imagen sea reconocida como el fundamento de la preocupación (Cohen, 1972) y de la comunidad del miedo (Beck, 1983). La ostentación delictual debe ser entendida como una acción sustentada en la propia lógica consumista y exhibicionista del capitalismo, que sitúan a la adquisición de elementos simbólicos como un verificador del currículo delictivo. Y también como un elemento que busca suplir la falta de historia y reconocimiento de los pares a través de la sobreexhibición del capital de daño. La ostentación en redes sociales es la visualización de la prominencia, es la disputa por su conceptualización a partir de la imposición del capital simbólico (Bourdieu, 1995, 2000; De Certeau, 2000). Ambas figuras se ven permeadas por el mismo atributo; los sujetos aparecen como grandes despilfarradores cuyo estilo de vida busca emular la estética del ídolo reguetonero que trasciende la marginalidad de su origen para brillar en la pantalla (Luci \& Soares, 2019), 

ostentación y prominencia en la subcultura delictual chilena. Revista de Sociología, 36(2), 21-33. https://doi.org/10.5354/0719-529X.2021.65568

gozar de la suntuosidad narco que ve en el dinero la posibilidad de existir estableciendo criterios de gusto y refinación (Reguillo, 2010; Rincón, 2009), y abrazar el consumo desproporcionado que lo emparenta con el artista o el futbolista de moda (Baudrillard, 2000; Zúñiga, 1991).

La ostentación del flaite-ladrón esta alojada en la experiencia, en su historia, en su trayectoria, elementos a partir de los cuales proyecta el conocimiento que se tiene de él a las redes sociales para la contemplación de sus pares. La exhibición misma se condice con su estar-siendo, y con su ha-venido-siendo en lo comunitario; esto, a diferencia del picao-a-choro que yergue la ostentación desde la vivencia mediática y sobreactuada del presente que solo habla de datos sueltos, información diseminada, donde el daño y temor compensen la falta de capital delictivo. El choro busca perfumar artificialmente el tiempo pretendiendo hacer del capital de daño un dato $\mathrm{y}$, de este dato, una historia donde la vivencia del temor se plantee como experiencia y la mera información como conocimiento real. El miedo y la violencia ostentada como valor hegemónico por el picao-a-choro en redes sociales busca aromatizar con efímeras esencias su imagen que ahora fuera de la contemplación busca un sentido de trascendencia en el juego que se ha iniciado en el ciber espacio, reproduciendo la nueva lógica delictual que pone al consumo y la inmediatez como indicadores de éxito, prestigio y poder.

\section{REFERENCIAS}

Augé, M. (1992). Los "no lugares" espacios del anonimato. Una antropología de la sobremodernidad. Gedisa.

Baudrillard, J. (2000). La sociedad del consumo. Siglo XXI.

Bauman, Z. (2008). Miedo líquido: La sociedad contemporánea y sus miedos líquidos. Paidós.

Bebord, G. (1967). La societe du spectacle. Editions Champ.

Beck, U. (1983). La sociedad del riesgo: Hacia una nueva modernidad. Paidós.

Bourdieu, P. (1997). Capital cultural, escuela y espacio social. Siglo XXI.

Bourdieu, P. (2000). Poder, derecho y clase social. Descleé de Brouwer.

Bude, H. (2017). La sociedad del miedo. Herder. Britto, D., \& Ordoñez, J. (2012). Las prácticas de distinción social. Polis. (11). http://journals.openedition.org/polis/5713.
Caro, L. (2012). Identidad mosaico: La encarnación del yo en las redes sociales digitales. Revista Telos, (91). https://bit.ly/3jEjXfv

Carosio, A. (2010). La cultura del consumo contra la sostenibilidad de la vida. Revista Sustentabilidades, (2). https://bit.ly/3EkDWrC

Cohen, A. (1955). Delinquent boy: The culture of the gang. Free Press of Glencoe.

Cohen, S. (1972). Demonios populares y "pánicos morales". Delincuencia juvenil, subcultura, vandalismo, drogas y violencia. Gedisa.

Cooper, D. (1989). Teoría del continuo subcultural de la delincuencia. Revista de Sociología, (4), 115-147. https://doi.org/10.5354/0719-529x.1989.27585

Cooper, D. (1994). Delincuencia común en Chile. LOM.

Cooper, D. (2007). Ideologías y tribus urbanas. LOM. 

ostentación y prominencia en la subcultura delictual chilena. Revista de Sociología, 36(2), 21-33. https://doi.org/10.5354/0719-529X.2021.65568

De Certeau, M. (2000). La invención de lo cotidiano 2. Habitar y cocinar. Universidad Iberoamericana.

Del Prete, A., \& Redon, S. (2020). Las redes sociales on-line: Espacios de socialización y definición de identidad. Psicoperspectivas, 19(1), 1-11. http://doi.org/10.5027/psicoperspectivasvol19-issue1-fulltext-1834

Domenech, M., \& Iñiguez, L. (2002). La construcción social de la violencia. Revista Athenea Digital, (2), 1-10.

https://doi.org/10.5565/rev/athenead/v1n2.54

Featherstone, M. (1991). Cultura del consumo y postmodernismo. Amorrortu.

Goffman, E. (1982). Interaction ritual - Essays on fase-to-face behavior. Panthenon Book.

Goffman, E. (1989). La presentación de la persona en la vida cotidiana. Amorrortu.

Guemureman, S. (2006). Ni bandas ni pandillas: La miopía de las teorías de las subculturas para explicar la violencia juvenil. Revista Temas Sociológicos, (11), 153-172.

https://doi.org/10.29344/07196458.11.207

Hütt, H. (2012). Las redes sociales: Una nueva herramienta de difusión. Revista Reflexiones 91(2), 121-128. https://www.redalyc.org/pdf/72 9/72923962008.pdf

Igarza, R. (2010). Nuevas formas de consumo cultural: Por qué las redes sociales están ganando la batalla de las audiencias. Revista Comunicação Mídia e Consumo, 7(20), 59-90. http://doi.org/10.18568/cmc.v7i20.205

Isla, A. (2011). Identificaciones de guerra. Rituales de hermandad entre jóvenes delincuentes en la Argentina contemporánea. En M. Ceberino (Coord), Más allá de las pandillas:
Violencias, juventudes y resistencias en el mundo globalizado (Vol. 1, pp. 73-92). FLACSO Ecuador.

Lasch, C. (1979). La cultura del narcisismo. Andrés Bello.

León, M. (2008). Extirpando el "jermen del mal": Visiones y teorías criminológicas en Chile contemporáneo (1911-1960). Revista Cuadernos de Historia, (28), 81-113. https://cuadernosdehistoria.uchile.cl/index.p hp/CDH/article/view/47294/49339

Lozoya, T. (2014). Delincuentes, bandoleros y montoneros. Violencia social en el espacio social rural chileno (1850-1870). LOM.

Luci, S., \& Soares, T. (2019). Reguetón en Cuba: Censura, ostentación y grietas en las políticas mediáticas. Revista Palabra Clave, 22(1), 1-28. https://doi.org/10.5294/pacla.2019.22.1.7

Moulian, T. (1998). El consumo me consume. LOM.

Muñoz, J. (1990). El papel de las normas en la definición de la agresión. Revista Boletín de Psicología, (26), 33-51. https://bit.ly/3pH2lDE

Palma, D. (2011). Ladrones: Historia social y cultural del robo en Chile, 1870-1920. LOM.

Pardo, M. (2015). La fascinación narcisista en la sociedad del consumo: Algunas reflexiones. Errancia. Revista de Psicoanálisis, Teoría Crítica y Cultura, 12. https://www.iztacala.unam.mx/errancia/v12 /errancia_12.html

Ponce-Cordero, R. (2016). Reguetón, narcocultura y bandidaje social en el filme Puertorriqueño "Talento de barrio". Mitologías Hoy. Revista de Pensamiento 

ostentación y prominencia en la subcultura delictual chilena. Revista de Sociología, 36(2), 21-33. https://doi.org/10.5354/0719-529X.2021.65568

$\begin{array}{lrrr}\text { Crítico } & y & \text { Estudios } & \text { Literarios } \\ \text { Latinoamericanos, } & 14, & 135-149 .\end{array}$

http://doi.org/10.5565/rev/mitologias.392

Reguillo, R. (2010). La narcomáquina y el trabajo de la violencia: Apuntes para su decodificación. Revista E-misférica, $8(2)$. https://hemisphericinstitute.org/es/emisferic a-82/reguillo5.html

Reygadas, L. (2018). Dones, falsos dones, bienes comunes y explotación en las redes sociales. Diversidad de la economía virtual. Revista Desacatos, (56), 70-89. https://doi.org/10.29340/56.1878

Rojas, D. (2015). Flaite: Algunos apuntes etimológicos. Revista Alpha, (40), 193-200. http://doi.org/10.4067/S0718-22012015000100015

Romero, A. (2017). Delincuencia juvenil: Neutralización, refutación y profusión. Olejnik.

Romero, A. (2018). Construcción de masculinidad y belleza masculina en jóvenes varones infractores consumidores problemáticos de drogas. Revista Última Década, 26(48), 107-132. http://doi.org/10.4067/S0718-22362018000100107

Romero, A. (2019). Prisionización: Estructura y dinámica del fenómeno en las cárceles estatales del sistema penal chileno. Revista Latinoamericana de Estudios de Seguridad, (24), 42-58. https://doi.org/10.17141/urvio.24.2019.3791

Rincón, O. (2009). Narco.estética y narco.cultura en narco.lombia. Revista Nueva Sociedad, (222), 147-163. https://nuso.org/articulo/narcoesteticay-narcocultura-en-narcolombia/
Ruggiero, V. (2005). Delitos de los débiles y de los poderosos. Ejercicios de anticriminología. Universidad de Buenos Aires; Universidad del Litoral; Ad-Hoc.

Salazar, G., \& Pinto, J. (1999). Historia contemporánea de Chile $V$. Niños y juventud. LOM.

Sánchez, S. (2016). Subculturas criminales: Un estudio de sociología de la desviación. Olejnik.

Sutherland, E. (1991). Ladrones profesionales. La Piqueta.

Tsukame, A. (2016a). Delincuencia juvenil y control social en el Chile neoliberal [Tesis Doctoral, Universidad Complutense de Madrid]. E-prints complutense. Repositorio institucional de la UCM. https://eprints.ucm.es/37504/

Tsukame, A. (2016b). El rol de los medios de comunicación en la construcción de discursos de guerra contra la delincuencia juvenil en Chile (1990-2016). Polis. Revista Latinoamericana, 15(44), 181-201. http://doi.org/10.4067/S071865682016000200009

Zúñiga, V. (1991). Los locos del barrio o la ostentación del estigma social y fronterizo en una pandilla de Matamoros, Tamaulipas. Rio Bravo: A bilingual journal of international Studies Fall, (1), 47-68. https://scholarworks.utrgv.edu/riobravojournal/1/

Manuscrito recibido: 03-07-2020 Manuscrito aceptado: 30-08-2021 